\title{
ZINC-LACCASE BIOFUEL CELL
}

\author{
AbDUl AZIZ AHMAD ${ }^{1}$, RAIHAN OTHMAN ${ }^{2}$, FARIDAH YUSOF ${ }^{1}$ \\ AND MOHAMAD FiRdAUS ABDUL WAHAB ${ }^{1}$ \\ ${ }^{1}$ Biotechnology Engineering Department, \\ ${ }^{2}$ Science in Engineering Department, \\ Faculty of Engineering, International Islamic University Malaysia \\ P.O. Box 10, 50728 Kuala Lumpur, Malaysia.
}

raihan@iium.edu.my

\begin{abstract}
A zinc-laccase biofuel cell adapting the zinc-air cell design features is investigated. A simple cell design configuration is employed: a membraneless single chamber and a freely suspended laccase in a quasi-neutral buffer electrolyte. The cell is characterised according to its open-circuit voltage, polarization profile, power density plot and discharge capacity at constant current. The biocatalytic role of laccase is evident from the polarization profile and power output plot. Performance comparison between a single chamber and dual chamber cell design is also presented. As anticipated, a single chamber cell design possesses lower power output as compared to the dual chamber cell design due to probably the charge leakage phenomenon. The biofuel cell possesses an open-circuit voltage of $1.2 \mathrm{~V}$ and delivered a maximum power density of $0.9 \mathrm{~mW} / \mathrm{cm}^{2}$ at current density of $2.5 \mathrm{~mA} / \mathrm{cm}^{2}$. These characteristics are comparable to biofuel cell utilising a much more complex system design.
\end{abstract}

ABSTRAK: Sel bio-bahan api zink-laccase dengan adaptasi daripada ciri-ciri rekabentuk sel zink-udara telah dikaji. Sel dengan konfigurasi rekabentuk yang mudah digunapakai: ruangan tunggal tanpa membran dan laccase diampaikan secara bebas di dalam elektrolit pemampan quasi-neutral. Sel dicirikan berdasarkan voltan litar terbuka, profil polarisasi, plot ketumpatan kuasa dan kapasiti discas pada arus malar. Peranan laccase sebagai biopemangkin adalah amat ketara daripada profil polarisasi dan plot ketumpatan kuasa. Perbandingan prestasi di antara sel dengan rekabentuk ruangan tunggal and dwi-ruangan turut diketengahkan. Seperti dijangkakan, sel dengan rekabentuk ruangan tunggal menunjukkan kuasa keluaran yang lebih rendah jika dibandingkan dengan rekabentuk dwi-ruangan kemungkinan disebabkan fenomena cas bocor. Sel bio-bahan api ini mempunyai voltan litar terbuka $1.2 \mathrm{~V}$ dan memberikan ketumpatan kuasa maksima 0.9 $\mathrm{mW} / \mathrm{cm}^{2}$ pada ketumpatan arus $2.5 \mathrm{~mA} / \mathrm{cm}^{2}$. Ciri-ciri ini adalah sebanding dengan sel bio-bahan api yang menggunapakai rekabentuk sel yang jauh lebih rumit.

KEYWORDS: biofuel cell; single chamber; zinc anode; enzyme; oxidoreductase

\section{INTRODUCTION}

One of the major fields of research in response to the need for preserving the environment is the research and development in renewable energy source to ease dependence on fossil fuel. Biofuel cell (BFC) is a potential clean energy substitute for fossil fuel. It is a clean, non-polluting, renewable energy source and producing benign byproduct as it produces energy - fondly dubbed as the nature's solution. Biofuel cell can be classified as an offspring of fuel cell technology. Unlike conventional fuel cells, biofuel cells utilize biological catalysts, either as they occur in microorganisms, or as isolated proteins rather than precious metals for the oxidation and reduction processes of fuel 
source [1]. Main types of biofuel cells depend on biocatalysts used. Microbial biofuel cells (MFC) employs whole living cells (microorganisms) whereas enzymatic biofuel cells (EFC) employs enzymes (functional proteins) [2]. EFCs have several positive attributes with respect to energy conversion, namely, the use of renewable catalysts, ability to operate at room temperature and physiological $\mathrm{pH}$, and possess much higher power densities as compared to MFC. In addition, enzymes have the added advantage of catalysing specific and defined reactions $[3,4]$.

The BFC system, however, is rather complex. The anolyte and catholyte of a BFC comprises of specific organic fuel or substrate, biocatalyst and electronophores or electron transfer mediators. Besides, each anolyte and catholyte requires a unique buffer condition for its optimum condition. Therefore, in this work we replaced the anolyte of a glucose oxidase-laccase BFC with an electropositive zinc metal producing a hybrid BFC - zinclaccase biocatalytic system. Consequently, it reduces the complexity of the BFC system, simplifies the design and makes the handling of the cell easier. In addition, we employed a simple design configuration - membraneless, single chamber cell and freely suspended laccase in buffer electrolyte. Unlike most prototypes of BFC which were tested under controlled or simulated conditions [5,6], the zinc-laccase cell developed in the present work was left to operate under open ambient surrounding. Yet, as shall be described succeedingly, its power density output is found comparable to biocatalytic cell employing much more complex system design and operating under controlled conditions.

Laccase belongs to the blue-multicopper oxidase family. Laccases (benzenediol:oxygen oxidoreductase, EC 1.10.3.2) are extracellular that use molecular oxygen to oxidize various aromatic and non-aromatic compounds by a radical catalysed reaction mechanism [7]. Due to its specific affinity towards oxygen, laccase is one of the industrial enzymes widely used in oxidative processes such as bioremediation, delignification, dye or stain bleaching, plant fibre modification, biosensors, biofuel cells, ethanol production etc. [8].

\section{EXPERIMENTAL SECTION}

\subsection{Cell Design and Components}

The cell comprised of zinc foil $(99.9 \%, 250 \mu \mathrm{m}$ thick) as the anode and a commercially available air electrode sheet as the cathode. The air electrode consisted of laminated structures of fibrous carbon supported by a nickel mesh. The air-side of the electrode was covered with a gas permeable, hydrophobic, Teflon membrane. The air electrode served both as the cathodic current collector as well as to feed ambient oxygen continuously into the system through its porous structure. The highly specific laccase reaction enables the use of a membraneless single compartment design. Cell was also constructed using dual chamber configuration. Cellophane and polypropylene polymeric separators were each utilized as the ionic exchange membrane. Fig. 1 depicts the photograph of the home-made, both the single and dual chamber cell designs, fabricated from acrylic boards.

\subsection{Electrolyte Formulation}

The electrolyte consisted of laccase and syringaldazine in potassium dihydrogen phosphate buffer. Laccase from Rhus vernicifera (120 Unit activity, U/mg) was sourced from Sigma-Aldrich. Laccase served as the biocatalyst for oxygen reduction, whereas syringaldazine was the phenolic substrate for laccase. Table 1 summarizes the electrolyte formulation used. 


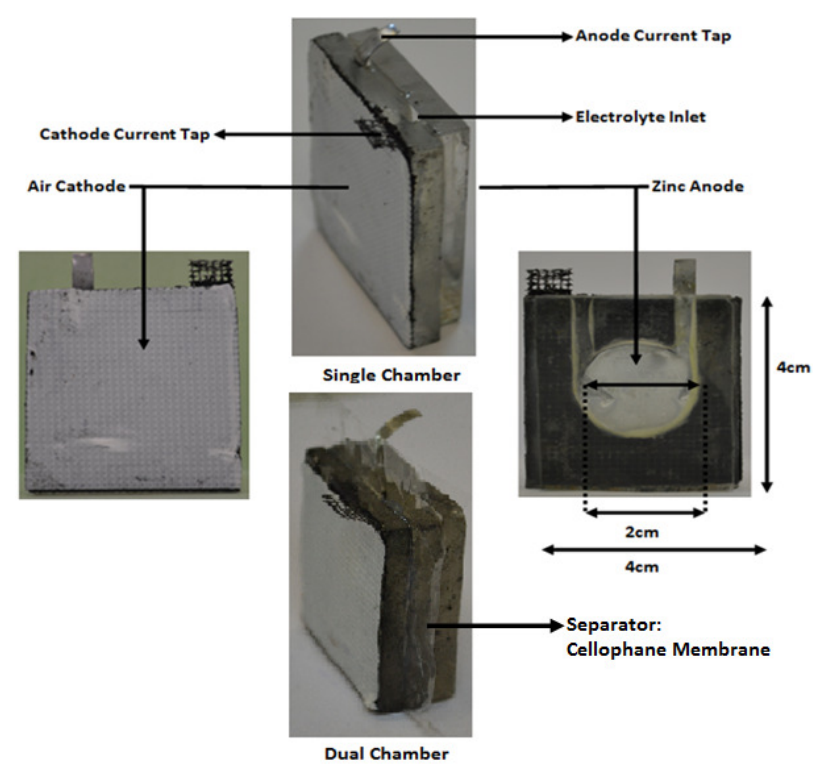

Fig. 1: Single and dual chamber cell designs.

Table 1: Electrolyte formulation of zinc-laccase biocatalytic cell.

\begin{tabular}{|c|c|c|c|}
\hline \multirow{2}{*}{ Electrolyte Component } & \multicolumn{2}{|c|}{ Stock } & \multirow{2}{*}{$\begin{array}{c}\text { Final Reaction Mix } \\
\text { Concentration }\end{array}$} \\
\cline { 2 - 3 } & Volume used & Concentration & $\begin{array}{c}36.5 \mathrm{mM} \text { potassium } \\
\text { phosphate }\end{array}$ \\
\hline Potassium phosphate buffer & $1100 \mu \mathrm{L}$ & $100 \mathrm{mM}$ & 25 units laccase \\
\hline $\begin{array}{c}\text { Catalyst: } \\
\text { Laccase from Rhus vernicifera }\end{array}$ & $250 \mu \mathrm{L}$ & $100 \mathrm{U} / \mathrm{mL}$ & $0.01 \mathrm{mM}$ syringaldazine \\
\hline $\begin{array}{c}\text { Substrate: } \\
\text { Syringaldazine in methanol }\end{array}$ & $150 \mu \mathrm{L}$ & $0.216 \mathrm{mM}$ & \multicolumn{2}{|c|}{$1500 \mu \mathrm{L}$} \\
\hline Total & \multicolumn{3}{|c}{} \\
\hline
\end{tabular}

Syringaldazine solution was prepared in absolute methanol. The electrolyte was prepared fresh in cold deionised water before each run. Laccase was assayed spectrophotometrically at $530 \mathrm{~nm}$ based on the following oxidative reaction to estimate the unit activity prior to electrolyte preparation.

- $\quad \underline{\text { Syringaldazine }+\mathrm{O}_{2}} \underline{\underline{\text { Laccase }}} \stackrel{\text { Oxidized Syringaldazine }+2 \mathrm{H}_{2}}{\longrightarrow} \underline{\mathrm{O}} \quad$ (Eq. 1)

This method was adopted from [9]. Figure 2 depicts the spectrophotometer scan of laccase/syringaldazine oxidative reaction in the 400-800 $\mathrm{nm}$ range which reaffirms the maximum absorbance detection at $530 \mathrm{~nm}$.

\subsection{Electrochemical Characterization}

The zinc-laccase biofuel cell was characterized based on its open-circuit voltage (OCV), polarization profile, power density plot and galvanostatic discharge capacity. An Eco Chemie Autolab Potentiostat/Galvanostat PGSTAT302N was utilized for the electrochemical tests. All experiments were conducted at room temperature. 


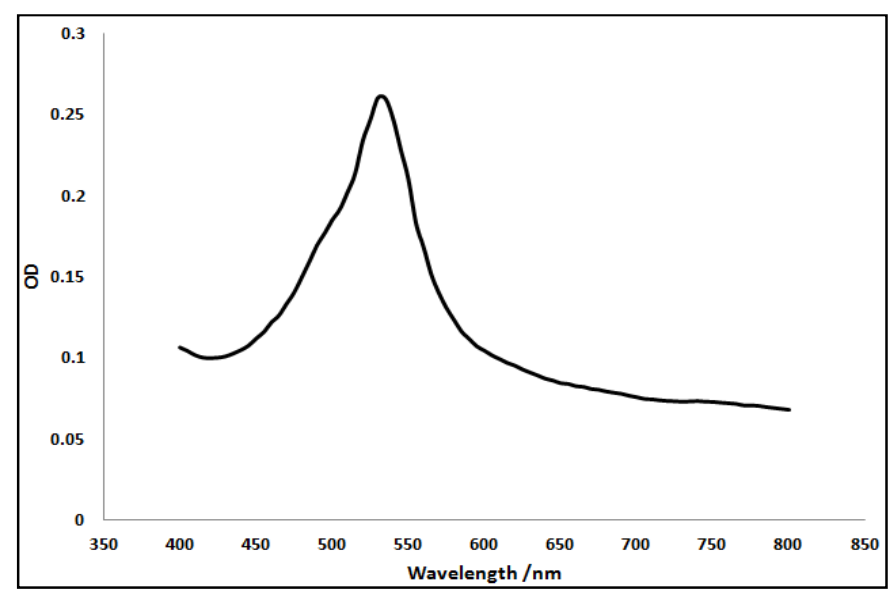

Fig. 2: Spectrophotometer scan of laccase/syringaldazine oxidative reaction.

A polarization profile is essentially a $V-I$ plot i.e. the variation of operating voltage as a function of discharge current. Theoretically, the plot is a horizontal straight line with an abrupt vertical line drop which marks the cell ceases to operate. The existence of internal resistance, concentration gradient and activation energy of each half electrode reaction resulted in the 'polarization' of the V-I profile. Power density plot can be subsequently obtained by measuring the cell power output, $\mathrm{P}$ (product of $V$ and $I$ ) at each particular discharge current. Based on the $P-I$ plot, the maximum power that the cell could deliver is readily obtained.

Cell discharge capacity is a measure of the total charge quantity that an electrochemical cell could supply. It is measured in ampere-hour or miliampere-hour (mAh) unit

$$
\text { Capacity, } C=I_{d} t
$$

$I_{d}$ is the constant discharge current and $t$ is the total discharge duration. The energy output of the cell can be obtained from the product of $I_{d}$ and the area under the discharge plot (operating voltage vs. time)

$$
\text { Energy output, } Q=I_{d} A_{n}=I_{d} \int_{t_{0}}^{t_{f}} V_{o p}(t) d t
$$

$A_{n}$ is the area under the discharge plot, $V_{o p}(t)$ is the instantaneous operating voltage of the cell, and $\Delta t=t_{f}-t_{0}$ is the discharge duration. $A_{n}$ can be estimated using the Riemann's Sum approximation

$$
A_{n}=\sum_{i=1}^{n} \Delta x f\left(c_{i}\right)
$$

$n$ is the number of data points, $\Delta x$ is the interval between data points, and $f\left(c_{i}\right)$ is the midpoint value between data point $i-1$ and $i(i=1,2,3, \ldots)$ i.e. the average cell potential value between successive data points.

\section{RESULTS AND DISCUSSION}

\subsection{Electrochemical Characterization}

The zinc-laccase biofuel cell registered an OCV of 1.2 V. The highest OCV for glucose oxidase-laccase biofuel cell was reported by Zebda and co-workers [10] i.e. 0.95 $\mathrm{V}$. They incorporated multi-walled carbon nanotubes (MWCNTs) into the compressed 
bioelectrode which served as a direct electrical wiring for glucose oxidase (GOx) and laccase. Thus, we have demonstrated that by substituting GOx with an electronegative zinc anode and merely employing freely suspended laccase, a biofuel cell with highest OCV was achieved. Further refinement of the zinc-laccase system which includes laccase immobilization, electrically wired laccase, utilization of mediator etc would definitely improve the OCV.

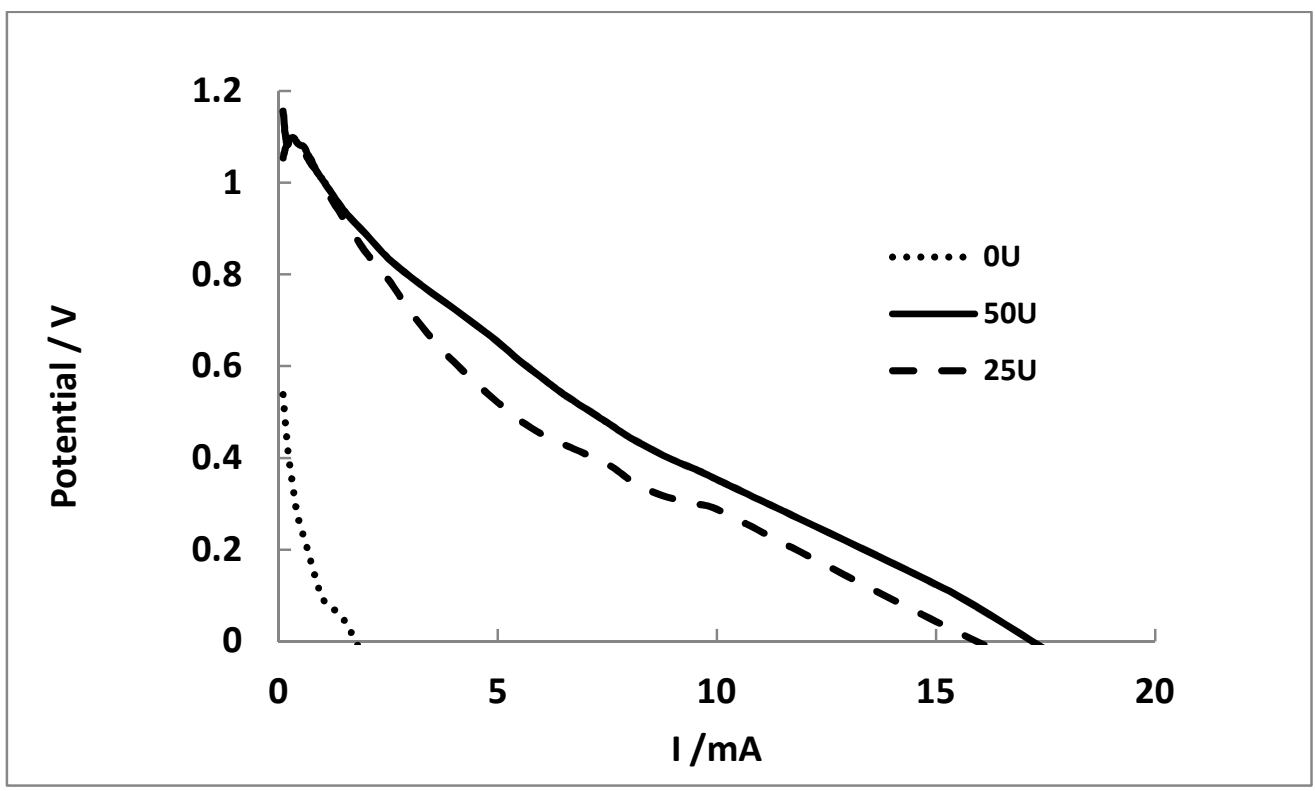

Fig. 3: Polarization profile of zinc-laccase biofuel cell employing different laccase loading.

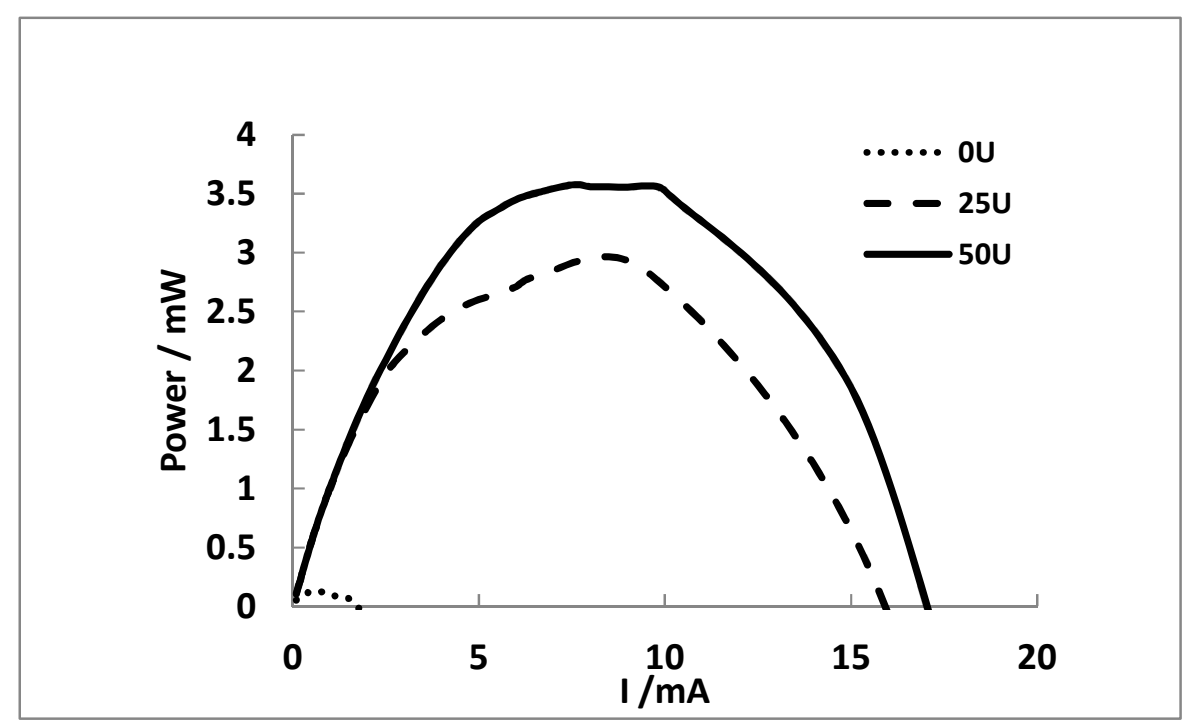

Fig. 4: Power density plots of zinc-laccase biofuel cell employing different laccase loading.

Figure 3 and 4 illustrate the polarization profile and the power density plot of zinclaccase biofuel cell, respectively. The cell was tested with $25 \mathrm{U}$ laccase, $50 \mathrm{U}$ laccase and $0 \mathrm{U}$ laccase i.e. a negative control cell. The polarization profiles and power density plots clearly substantiate the biocatalytic role of laccase. A marked enhancement was observed 
with the inclusion of laccase into the electrolyte and further improvement was noticed as the quantity of laccase was doubled. Note that from the power density plot, a maximum power output is obtained at $8 \mathrm{~mA}$ discharge current i.e. $2.8 \mathrm{~mW}$ and $3.6 \mathrm{~mW}$ for $25 \mathrm{U}$ laccase and $50 \mathrm{U}$ laccase respectively.

Figure 5 shows the discharge capability of zinc-laccase biofuel cell performed at constant current of $0.25 \mathrm{~mA}, 0.5 \mathrm{~mA}$ and $1.0 \mathrm{~mA}$. All cells employed $25 \mathrm{U}$ laccase. The resulting cell capacity was $3.7 \mathrm{mAh}, 5.9 \mathrm{mAh}$ and $4.5 \mathrm{mAh}$, respectively. Cell capacity is an empirical quantity which is dependent on discharge current. The polarization profile of Fig. 3 can be used to gauge the capability of the cell to discharge at higher current density.

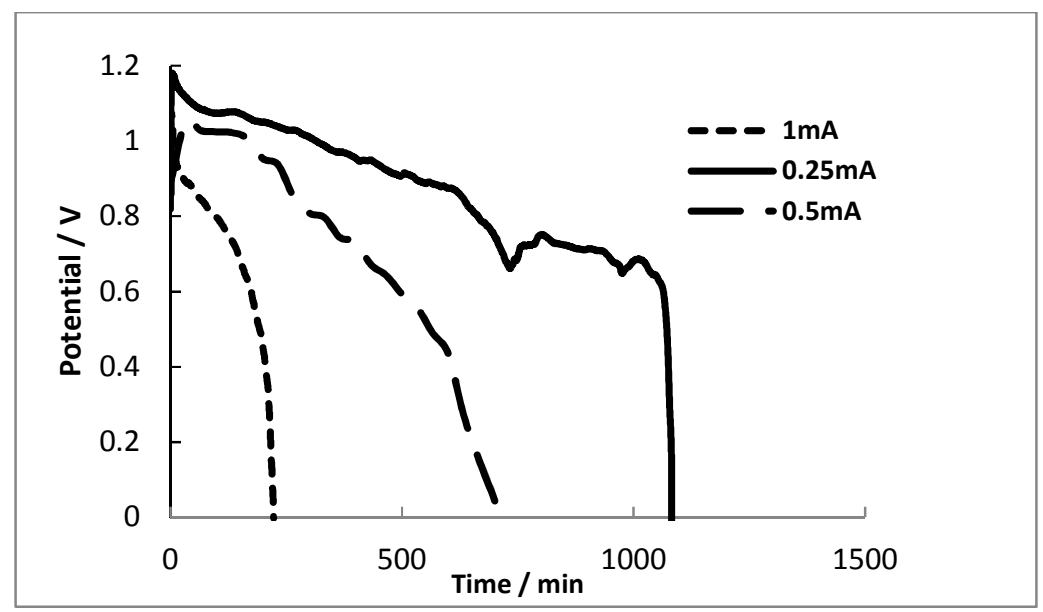

Fig. 5: Discharge curves of zinc-laccase biofuel cell.

\subsection{Single Chamber and Dual Chamber Design Analysis}

One of the unique features of functional proteins or enzymes is their highly specific reaction. This characteristic permits the use of a membraneless, single compartment zinclaccase biofuel cell design [11]. However, the simple membraneless, single chamber design is at the expense of a reduced power output. When zinc oxidizes into zinc ions, the electrons released should be channelled to the air electrode or cathodic current collector through the external circuit. These electrons are in turn utilized to reduce oxygen molecules. In the absence of an ionic exchange membrane in a single chamber design, these electrons could be passed directly to laccase to reduce dissolved oxygen. A phenomenon termed as current or charge leakage.

In order to investigate the charge leakage phenomena in the present membraneless cell configuration, a zinc-laccase system with dual chamber design was also investigated. Two types of ionic exchange membrane were tested i.e. cellophane and polypropylene. Cellophane membrane is commonly used for biofuel cells of dual chamber design $[15,16]$. Polypropylene membrane, on the other hand, is normally employed in lithium and proton secondary cells. Both cells were discharged at a constant current of $0.5 \mathrm{~mA}$. Figure 6 displays the results. Zinc-laccase system using cellophane separator showed better discharge profiles; the operating voltage was higher for most of the discharge duration and the discharge lasted slightly longer. Polypropylene separator seemed not suitable for use in zinc-laccase system; the cell could only be discharged at $5 \mu \mathrm{A}$. By comparing the area under the discharge curve, the single chamber zinc-laccase cell delivered $15.2 \mathrm{~J}$ of energy while utilizing cellophane resulted in $10 \%$ energy output enhancement i.e. 16.8 J. Thus, 
the occurrence of charge leakage was observed in the membraneless, single chamber cell design.

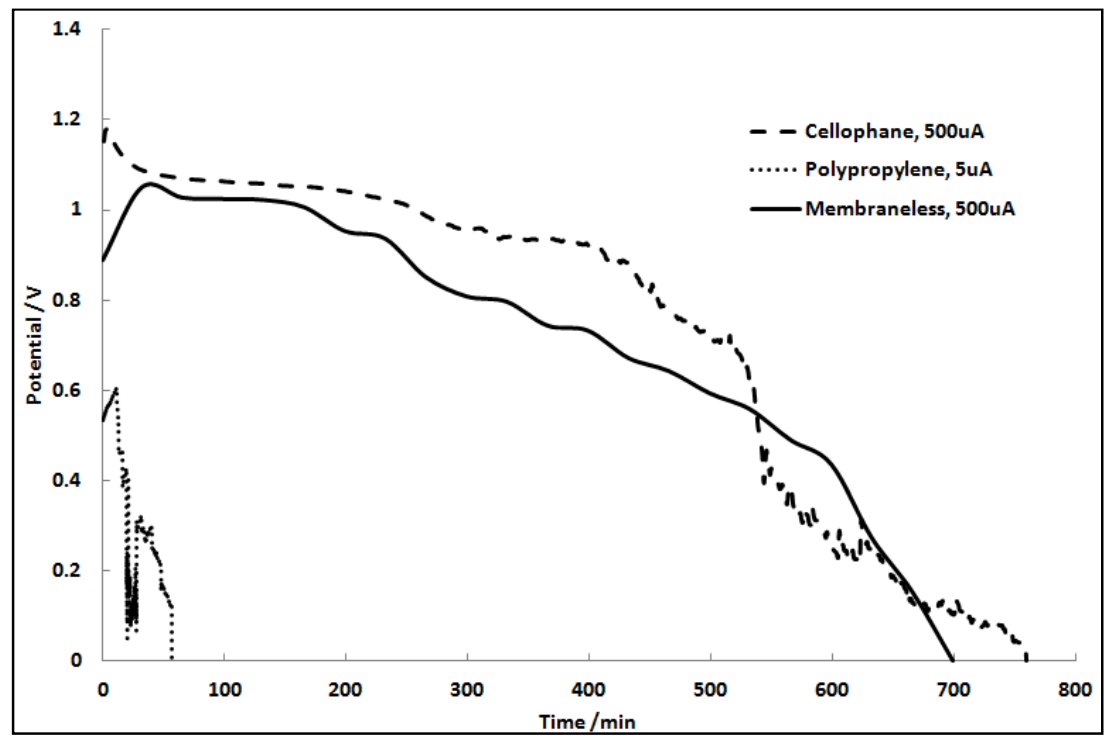

Fig. 6: Discharge performance comparison between dual chamber cell and single chamber (membraneless) cell.

\subsection{Zinc-Laccase Biofuel Cell Performance Analysis}

Reports in the literature on zinc-laccase biocatalytic system are scarce and to the best of our knowledge the only published work is by Smolander and co-workers [13]. They coupled zinc anode with laccase biocathode. The biocathode consisted of a mixture of laccase from T. hirsuta, ABTS electron mediator (2,2' Azino-bis(3-ethylbenzthiazoline-6sulfonic acid)), and MWCNTs, in succinate buffer of $\mathrm{pH}$ 4.5. The zinc-laccase system operated under humidity controlled conditions and oxygenated electrolyte in double chamber design utilizing cellophane, Nafion or Whatman 1 filter paper as separator. They observed a higher OCV of $1.45 \mathrm{~V}$ for the zinc-laccase system. The optimum cell configuration possessed a maximum power density around $10 \mu \mathrm{W} / \mathrm{cm}^{2}$ at discharge current of $39 \mu \mathrm{A} / \mathrm{cm}^{2}$, obtained under humidity controlled condition and closed system.

On the other hand, the present work studied an open zinc-laccase system in which an air electrode was utilized to permit direct air (oxygen) access to the system, and the cell was left to operate under open ambient conditions. Basically the system design resembles zinc-air cell which employed laccase as the oxygen reduction catalyst. Furthermore, we adopted a much simpler design: membraneless (single-chamber cell) and freely suspended laccase (not immobilized) in quasi-neutral buffer electrolyte. We obtained a maximum power density an order of magnitude higher i.e. $0.9 \mathrm{~mW} / \mathrm{cm}^{2}$ at current density of 2.5 $\mathrm{mA} / \mathrm{cm}^{2}$ (based on $25 \mathrm{U}$ laccase formulation, $2.8 \mathrm{~mW}$ maximum power and electrode size of $\pi \times 1 \mathrm{~cm}^{2}$ ). Direct comparison of discharge capacity is not possible since they characterized the cell under constant load of $2.2 \mathrm{k} \Omega$. 


\section{CONCLUSION}

A zinc-laccase biofuel cell adapting the zinc-air cell design configuration has been investigated. Unlike most biofuel cells, the cell operated under open ambient conditions. A single chamber, membraneless cell design was utilized. Laccase biocatalyst was left to be freely suspended (i.e. not immobilized) in quasi-neutral potassium dihydrogen phosphate buffer ( $\mathrm{pH}$ 6.5) electrolyte. Despite its simple design features and operated not under controlled conditions, the zinc-laccase system studied demonstrated power output of comparable performance to biofuel cell system utilizing a much more complex design immobilized enzyme and electron transfer mediator, controlled temperature and humidity, oxygenated electrolyte etc. The present biofuel system demonstrated attractive features to be further developed.

\section{ACKNOWLEDGEMENT}

The authors gratefully acknowledge the International Islamic University Malaysia for the funding of this project through the IIUM Research Endowment Fund (EDW B 0902-227).

\section{REFERENCES}

[1] Palmore GT, Whitesides GM: Microbial and enzymatic biofuel cells. ACS Sym Ser 1994, 566:271-290.

[2] Minteer SD, Liaw BY, Cooney MJ: Enzyme-based biofuel cells. Curr Opin Biotech 2007, 18:228-234.

[3] Bond DR, Lovley DR: Evidence for Involvement of an Electron Shuttle in Electricity Generation by Geothrix fermentans. Appl Environ Microbiol 2005, 71:2186-2189.

[4] Bullen RA, Arnot TC, Lakeman JB, Walsh FC: Biofuel cells and their development. Biosens Bioelectron 2006, 21:2015-2045.

[5] Habrioux A, Merle G, Servat K, Kokoh KB, Innocent C, Cretin M, Tingry S: Concentric glucose/O2 biofuel cell. J Electroanal Chem. 2008, 622:97-102.

[6] Mano N, Kim HH, Zhang Y, Heller A: An oxygen cathode operating in a physiological solution. J Am Chem Soc 2002, 124:6480-6486.

[7] Thurston CF: The structure and function of fungal laccases. Microbiology 1994, 140:19-26.

[8] Alcalde M: Laccases: biological functions, molecular structure and industrial applications. In Industrial Enzymes. Edited by Polaina $\mathbf{J}$ and MacCabe AP. Netherlands: Springer; 2007:461-476.

[9] Ride J: The effect of induced lignification on the resistance of wheat cell walls to fungal degradation. Physiol Plant Pathol 1980:187-196.

[10] Zebda A, Gondran C, Le Goff A, Holzinger M, Cinquin P, Cosnier S: Mediatorless high-power glucose biofuel cells based on compressed carbon nanotube-enzyme electrodes. Nat Commun 2011, 2:370.

[11] Heller A: Potentially implantable miniature batteries. Anal Bioanal Chem. 2006, 385:469-473.

[12] Sakai H, Nakagawa T, Tokita Y, Hatazawa T, Ikeda T, Tsujimura S, Kano K: A high-power glucose/oxygen biofuel cell operating under quiescent conditions. Energy Environ Sci 2009, 2:133-138.

[13] Smolander M, Boer H, Valkiainen M, Roozeman R, Bergelin M, Eriksson J-E, Zhang XC, Koivula A, Viikari L: Development of a printable laccase-based biocathode for fuel cell applications. Enzyme Microb Tech 2008, 43:93-102. 